\title{
Protein intake induced an increase in exercise stimulated fat oxidation during stable body weight.
}

Citation for published version (APA):

Soenen, S., Plasqui, G., Smeets, A. J., \& Westerterp-Plantenga, M. S. (2010). Protein intake induced an increase in exercise stimulated fat oxidation during stable body weight. Physiology \& Behavior, 101(5), 770-774. https://doi.org/10.1016/j.physbeh.2010.08.019

Document status and date:

Published: 01/01/2010

DOI:

10.1016/j.physbeh.2010.08.019

Document Version:

Publisher's PDF, also known as Version of record

Document license:

Taverne

Please check the document version of this publication:

- A submitted manuscript is the version of the article upon submission and before peer-review. There can be important differences between the submitted version and the official published version of record.

People interested in the research are advised to contact the author for the final version of the publication, or visit the DOI to the publisher's website.

- The final author version and the galley proof are versions of the publication after peer review.

- The final published version features the final layout of the paper including the volume, issue and page numbers.

Link to publication

\footnotetext{
General rights rights.

- You may freely distribute the URL identifying the publication in the public portal. please follow below link for the End User Agreement:

www.umlib.nl/taverne-license

Take down policy

If you believe that this document breaches copyright please contact us at:

repository@maastrichtuniversity.nl

providing details and we will investigate your claim.
}

Copyright and moral rights for the publications made accessible in the public portal are retained by the authors and/or other copyright owners and it is a condition of accessing publications that users recognise and abide by the legal requirements associated with these

- Users may download and print one copy of any publication from the public portal for the purpose of private study or research.

- You may not further distribute the material or use it for any profit-making activity or commercial gain

If the publication is distributed under the terms of Article $25 \mathrm{fa}$ of the Dutch Copyright Act, indicated by the "Taverne" license above, 


\title{
Protein intake induced an increase in exercise stimulated fat oxidation during stable body weight ${ }^{\stackrel{\hbar}{\hbar}}$
}

\author{
Stijn Soenen *, Guy Plasqui, Astrid J. Smeets, Margriet S. Westerterp-Plantenga \\ Department of Human Biology, Nutrition and Toxicology Research Institute Maastricht (NUTRIM), Top Institute Food and Nutrition (TIFN), Maastricht University, \\ P.0. Box 616, 6200 MD Maastricht, The Netherlands
}

\section{A R T I C L E I N F O}

\section{Article history:}

Received 20 June 2009

Received in revised form 24 August 2010

Accepted 27 August 2010

\section{Key words:}

Protein intake

Fat oxidation

Fat mass

Fat-free mass

Fat percentage

\begin{abstract}
A B S T R A C T
Background: Protein-rich weight-loss diets spare fat-free mass at the cost of fat mass. The objective was to examine if there is a change in stimulated fat oxidation related to protein intake during stable body weight. Methods: Subjects' (BMI $22 \pm 2 \mathrm{~kg} / \mathrm{m}^{2}$, age $25 \pm 8$ years) maximal fat oxidation (Fat ${ }_{\max }$ ) was assessed during a graded bicycle test, before and after a 3-month dietary-intervention of $2 \mathrm{MJ} /$ day supplements exchanged with $2 \mathrm{MJ} / \mathrm{d}$ of habitual energy intake. The parallel design consisted of protein-rich supplements in the protein group and an isocaloric combination of carbohydrate and fat supplements in the control group. Daily protein intake was determined according to 24-h urine nitrogen. Body composition was measured according to a 4-compartment model by a combination of underwater-weighing technique, deuterium-dilution technique and whole-body dual-energy X-ray absorptiometry (DXA).

Results: Subjects were weight stable and did not change their physical activity. The protein group $(n=12)$ increased protein intake $(11 \pm 14 \mathrm{~g}, P<0.05)$ and had significantly higher daily protein intake vs. control $(n=4)$ ( $80 \pm 21$ vs.59 $\pm 11 \mathrm{~g}, P<0.05)$. Fat ${ }_{\max }$ increased significantly in the protein group $(0.08 \pm 0.08 \mathrm{~g} / \mathrm{min}, P<0.01)$. Fat-free mass increased independent of change in body weight $(P<0.01)$, and fat mass and fat percentage decreased $(P<0.05)$. Change in Fat max $_{\text {ax }}$ was a function of change in protein intake $(r=0.623, P<0.05)$, and not of changes in body composition or $\mathrm{VO}_{2} \max$.

Conclusion: Increased stimulated fat oxidation was related to increased protein intake.
\end{abstract}

(c) 2010 Elsevier Inc. All rights reserved.

\section{Introduction}

Obesity is a condition in which fat mass (FM) and fat percentage are increased [1] and levels of fat oxidation are suggested to be disturbed [2]. Fat and carbohydrate oxidation are mainly influenced by exercise intensity [3]. With increasing exercise intensity, fat oxidation first increases to its maximal fat oxidation rate ( $\mathrm{Fat}_{\max }$ ) from low- to moderate-exercise intensities and then decreases from moderate- to high-exercise intensities [3]. The daily majority of energy demand is at rest or during moderate-exercise intensity. At rest and during moderate-exercise intensity, fat oxidation is the main source of energy production for the body [4]. So, moderate-exercise intensity yields the most grams of fat used for oxidation and could therefore play a role in the maintenance of or reduction in FM. The desired goal for the treatment of and the reduction in development of obesity is to decrease FM while preserving or increasing fat-free mass (FFM). Increased protein intake has shown to result in greater loss of

\footnotetext{
is This study was supported by Top Institute Food and Nutrition (Wageningen, The Netherlands).

* Corresponding author. Department of Human Biology, Maastricht University, P.O. Box 616, 6200 MD Maastricht, The Netherlands. Tel.: + 3143 3882123; fax: + 3143 3670976.

E-mail address: S.Soenen@HB.unimaas.nl (S. Soenen).
}

FM and lower loss of FFM during energy restriction, and lower regain of FM and greater regain of FFM during weight regain after weight loss [5-7]. The resulted higher ratio of FFM to FM plays an important role in the maintenance of energy balance [8] and the preservation of metabolic and overall health $[9,10]$. Since elevated protein intake results in a more favorable body composition during weight loss and weight maintenance thereafter, and since FM is mainly reduced during moderate-exercise intensity, the question remains whether these characteristics hold when subjects are in conditions of energy balance. Therefore, the aim of this study was to investigate whether a change in dietary protein might change stimulated fat oxidation during exercise in subjects with constant body weight over time.

\section{Subjects and methods}

\subsection{Subjects}

Subjects were recruited by means of an advertisement in local newspapers and on notice boards at Maastricht University. Subjects who were willing to participate in the study were subsequently screened, by means of a detailed medical history and a physical examination. All subjects were in good health, non-smokers, at most moderate alcohol users, did not use prescription medication, and did not 
fluctuate more than $2 \mathrm{~kg}$ in body mass over at least the last 2 months. All subjects gave a written informed consent. The Medical Ethics committee of the University and Academic Hospital of Maastricht approved the study. Twenty-five subjects started in the study, 11 men and 14 women. Eight subjects ( 5 men and 3 women, and 4 subjects in each group) dropped out due to several reasons, such as personal and an inability to fulfill the schedule with visits to the university. Dropouts were not different from completers in baseline body weight, BMI and body composition, Fat max $_{\text {, }}$ physical activity or protein intake. One subject of the control group had excessive protein intake at baseline $(216 \mathrm{~g}$ at baseline and $89 \mathrm{~g}$ during the intervention), and was removed from the analysis. Subject characteristics ( $n=16 ; 12$ in the protein group and 4 in the control group) are given in Table 1.

\subsection{Study design}

The study had a randomized parallel design and consisted of a dietary intervention period of 3 months. A test day that included measurement of substrate oxidation during a graded bicycle test to exhaustion, measurements of body composition, blood sampling and completing questionnaires took place at baseline and after 3 months of intervention. Subjects were familiarized with the equipment and the procedures before the start of all measurements. Measurements were performed in the morning after an overnight fast. The bicycle-ergometer test started at the same time in the morning to avoid circadian variance. The day before both test days, subjects were asked to refrain from alcohol, refrain from indulgement in strenuous exercise and refrain from eating and drinking after 11:00 PM. Subjects were instructed to maintain their baseline body weight and to maintain their customary level of physical activity during the entire duration of the study.

\subsection{Dietary intervention}

Subjects were counseled to consume isocaloric diets to sustain body weight by exchanging $2 \mathrm{MJ}$ of their habitual energy intake with $2 \mathrm{MJ}$ supplements. The protein group received protein supplements consisting of milk-proteins to be incorporated within the subjects' habitual diets to increase daily protein intake. These protein supplements were rich in essential micronutrients and were supplied in three sachets daily containing in total of $52 \mathrm{~g}$ of milk-protein, dissolved in water to obtain a milk shake, pudding, soup or muesli (Modifast, Novartis Nutrition, Breda, The Netherlands). The control group received isocaloric carbohydrate-fat supplements consisting of a limonade (Karvan Cevitam, Koninklijke de Ruijter, Zeist, The Netherlands) and of olive oil. All subjects were instructed to consume daily at least $200 \mathrm{~g}$ of fruit and $300 \mathrm{~g}$ of vegetables.

To asses dietary protein intake, subjects completed three 24-h urine collections at baseline and in weeks 6 and 12. Samples were samples were collected with $10 \mathrm{~mL} \mathrm{H}_{2} \mathrm{SO}_{4}$ to prevent nitrogen loss through evaporation, stored frozen at $-20^{\circ} \mathrm{C}$, and later analyzed for urinary nitrogen with a nitrogen analyzer (CHN-O-Rapid; Heraeus, Hanau, Germany).

\subsection{Anthropometry}

To monitor body weight stability, subjects were instructed to measure their body weight daily at home. At the University, body weight was measured 2-weekly using a digital balance (Chyo-MW$150 \mathrm{~K}$, Chyo, Japan; weighing accuracy $0.02 \mathrm{~kg}$ ) with subjects in underwear, in the fasted state and after voiding their bladder. If body weight fluctuated by $>2 \mathrm{~kg}$ from baseline body weight, subjects were instructed to adjust their energy intake to encourage a return to and maintenance of baseline body weight. Height was measured at baseline to the nearest $0.1 \mathrm{~cm}$ using a wall-mounted stadiometer (Seca, model 220, Hamburg, Germany). Body mass index (BMI) was calculated by dividing body weight by height squared $\left(\mathrm{kg} / \mathrm{m}^{2}\right)$.

\subsection{Body composition}

Body composition was assessed in the fasted state with the 4compartment model of Lohman [11]. The model was used to calculate percentage fat mass (\%FM) from the independently determined wholebody density (Db), total body water (TBW) and total bone mineral content (BMC). Measuring whole-body density, total body water and total bone mineral content separately increases the accuracy of FFM and FM at baseline and after the intervention and is therefore more suitable to determine changes in FFM and FM, especially if subjects sustain their body weight. All measurements were completed within the same

Table 1

Subject characteristics of the 3-month dietary intervention period.

\begin{tabular}{|c|c|c|c|c|c|c|}
\hline \multirow{3}{*}{ Group } & \multicolumn{3}{|l|}{ Baseline } & \multicolumn{3}{|l|}{3 months } \\
\hline & \multirow{2}{*}{$\frac{\text { Total }}{N=16}$} & \multirow{2}{*}{$\frac{\text { Control }}{N=4}$} & \multirow{2}{*}{$\begin{array}{l}\text { Protein } \\
N=12\end{array}$} & \multirow[t]{2}{*}{ Total } & \multirow[t]{2}{*}{ Control } & \multirow[t]{2}{*}{ Protein } \\
\hline & & & & & & \\
\hline Age (years) & $24.6 \pm 7.6$ & $24.8 \pm 9.2$ & $24.6 \pm 7.5$ & & & \\
\hline Body height $(\mathrm{cm})$ & $172.7 \pm 10.0$ & $172.9 \pm 2.1$ & $172.7 \pm 11.7$ & & & \\
\hline Body weight (kg) & $66.0 \pm 8.6$ & $65.5 \pm 3.7$ & $66.1 \pm 9.9$ & $66.3 \pm 8.6$ & $66.1 \pm 4.0$ & $66.3 \pm 9.8$ \\
\hline BMI $\left(\mathrm{kg} / \mathrm{m}^{2}\right)^{\mathrm{a}}$ & $22.1 \pm 1.7$ & $21.9 \pm 1.7$ & $22.1 \pm 1.8$ & $22.2 \pm 1.9$ & $22.1 \pm 1.8$ & $22.2 \pm 2.0$ \\
\hline FFM $(\mathrm{kg})^{\mathrm{b}}$ & $52.1 \pm 10.8$ & $51.9 \pm 3.4$ & $52.1 \pm 12.5^{*}$ & $52.9 \pm 11.5$ & $51.1 \pm 4.3$ & $53.6 \pm 13.2^{*}$ \\
\hline $\mathrm{FM}(\mathrm{kg})^{\mathrm{b}}$ & $13.7 \pm 4.5$ & $13.6 \pm 4.6$ & $13.8 \pm 4.7^{*}$ & $13.2 \pm 5.1$ & $15.0 \pm 4.8$ & $12.6 \pm 5.3^{*}$ \\
\hline FM $(\%)^{\mathrm{b}}$ & $21.4 \pm 7.7$ & $20.6 \pm 6.1$ & $21.6 \pm 8.4^{*}$ & $20.5 \pm 8.4$ & $22.5 \pm 6.4$ & $19.9 \pm 9.1^{*}$ \\
\hline $\mathrm{FFA}(\mu \mathrm{mol} / \mathrm{L})^{\mathrm{c}}$ & $427 \pm 121$ & $409 \pm 94$ & $433 \pm 132$ & $420 \pm 169$ & $594 \pm 136$ & $391 \pm 160$ \\
\hline Protein intake $(\mathrm{g})^{\mathrm{d}}$ & $67 \pm 17$ & $58 \pm 13$ & $70 \pm 17^{*}$ & $75 \pm 21$ & $59 \pm 11$ & $80 \pm 21^{*}$ \\
\hline Protein intake/body weight $(\mathrm{g} / \mathrm{kg})^{\mathrm{d}}$ & $1.0 \pm 0.2$ & $0.9 \pm 0.2$ & $1.1 \pm 0.2^{*}$ & $1.1 \pm 0.3$ & $0.9 \pm 0.1$ & $1.2 \pm 0.2^{*}$ \\
\hline $\mathrm{Fat}_{\max }(\mathrm{g} / \mathrm{min})$ & $0.43 \pm 0.10$ & $0.52 \pm 0.12$ & $0.43 \pm 0.11^{*}$ & $0.52 \pm 0.11$ & $0.55 \pm 0.04$ & $0.51 \pm 0.11^{*}$ \\
\hline $\mathrm{VO}_{2} \max (\mathrm{mL} / \mathrm{min})$ & $2804 \pm 855$ & $2549 \pm 597$ & $2889 \pm 932$ & $2946 \pm 862$ & $3004 \pm 508$ & $2935 \pm 930$ \\
\hline $\mathrm{VO}_{2} \mathrm{max} / \mathrm{FFM}(\mathrm{mL} / \mathrm{min} / \mathrm{kg})$ & $50.6 \pm 7.4$ & $46.7 \pm 9.5$ & $51.9 \pm 6.5$ & $54.1 \pm 6.2$ & $57.0 \pm 2.3$ & $53.6 \pm 6.6$ \\
\hline Baecke $\mathrm{e}^{\mathrm{e}}$ & $9.2 \pm 1.4$ & $8.8 \pm 1.0$ & $9.4 \pm 1.5$ & $9.0 \pm 1.0$ & $9.0 \pm 0.7$ & $9.1 \pm 1.1$ \\
\hline Sport $\mathrm{e}^{\mathrm{e}}$ & $3.5 \pm 0.9$ & $3.6 \pm 0.7$ & $3.5 \pm 0.9$ & $3.5 \pm 0.7$ & $3.6 \pm 0.7$ & $3.4 \pm 0.7$ \\
\hline Leisure time $\mathrm{e}^{\mathrm{e}}$ & $3.5 \pm 0.4$ & $3.3 \pm 0.4$ & $3.5 \pm 0.5$ & $3.4 \pm 0.5$ & $3.3 \pm 0.4$ & $3.5 \pm 0.5$ \\
\hline Work $^{\mathrm{e}}$ & $2.3 \pm 0.7$ & $2.1 \pm 0.2$ & $2.4 \pm 0.8$ & $2.1 \pm 0.5$ & $2.1 \pm 0.2$ & $2.1 \pm 0.6$ \\
\hline
\end{tabular}

Mean values and standard deviations.

${ }^{*} P<0.05, P$-value of paired Student's $t$-test over time, baseline compared to after 3 months

a Body mass index $\left(\mathrm{BMI} \mathrm{kg} / \mathrm{m}^{2}\right.$ ) was calculated as body weight $(\mathrm{kg})$ divided by height $(\mathrm{m})$ squared.

b Body composition of the 4-compartment model of Lohman; \%FM = (274.7/Db - 71.4 TBW/BM +114.6 BMC/BM - 205.03).

c Based on 24-h urinary nitrogen content, 3-month value is the average of 1.5 and 3 months.

d Plasma concentrations after overnight fasting, $n=15$ at 3 months.

e The Baecke total activity index and its activity subscores of sport, leisure time and work. 
morning. The used equation of Lohman was $\% \mathrm{FM}=(2.747 / \mathrm{Db}-0.714 \times$ $\mathrm{TBW} / \mathrm{BM}+1.146 \times \mathrm{BMC} / \mathrm{BM}-2.0503) \times 100$ [11].

Whole-body density was measured with the underwater weighing technique. Body mass in air and underwater was determined on a digital balance, accurate to $0.01 \mathrm{~kg}$ (Sauer type E1200). Residual lung volume was measured simultaneously with the helium dilution technique using a spirometer (Volugraph 2000, Mijnhardt, The Netherlands).

Total body water was measured using the deuterium $\left({ }^{2} \mathrm{H}_{2} \mathrm{O}\right)$ dilution technique according to the Maastricht protocol [12]. In the evening before the test day, subjects collected a background urine sample and then ingested a dose of deuterium-enriched water, after which they refrained from consuming fluid and food. The following morning, a urine sample from the second voiding was collected between 08:00 and 10:00 h. The concentration of deuterium in the urine samples was measured using an isotope ratio mass spectrometer (Micromass Optima, Manchester, UK). The dilution of the deuterium isotope is a measure for TBW. Total body water was obtained by dividing the measured deuterium dilution space by 1.04 to correct for exchange of the ${ }^{2} \mathrm{H}$ label with non-aqueous hydrogen of body solids [13].

Total bone mineral content (BMC) was measured using dual-energy X-ray absorptiometry (DXA; Lunar Corp., Madison, WI) with a resolution of $4.8 \times 9.6 \mathrm{~mm}$ (whole-body). Bone content and density were calculated by Lunar software (version 1.3z). The subjects wore loose metal free clothing and remained in a supine position while scanning was completed. The results were compared with the Germany Total Body White Reference Population provided by the manufacturer.

\subsection{Substrate oxidation during the cycle-ergometer test}

Subjects performed a graded exercise test to exhaustion on an electromagnetically braked bicycle ergometer (Excalibur, Lode, Groningen, The Netherlands). Simultaneous indirect calorimetric breath-bybreath measurements enabled to measure fat oxidation rate over a wide range of intensities. Fat oxidation rate was plotted against exercise intensity, expressed as $\% \mathrm{VO}_{2} \mathrm{max}$, power output and heart rate, constructing a fat oxidation curve to accurately determine maximum fat oxidation $\left(\right.$ Fat $\left._{\max }\right)$. The cycle ergometer protocol has been validated to determine the exercise intensity that elicits Fat ${ }_{\max }$ [14]. Moreover, it has been shown that the early stages of this type of protocol do not influence the exercise intensity at Fat ${ }_{\text {max }}[14]$.

Workload of the cycle ergometer test was calculated for each subject to standardize the cycling protocol between subjects. Subjects started cycling at a workload of $0.5 \mathrm{~W} / \mathrm{kg}$ FFM. Workload was increased by $0.5 \mathrm{~W} / \mathrm{kg}$ FFM every 3 min until exhaustion. Maximal workload was calculated as the last completed stage plus the fraction of time spent in the final non-completed stage multiplied by the workload increment.

Indirect calorimetric measurements were performed using an Omnical IV gas analysis system. The gas analyzers were calibrated with a $18 \% \mathrm{O}_{2} / 0.8 \% \mathrm{CO}_{2} / 81.2 \% \mathrm{~N}_{2}$ gas mixture with an uncertainty of $1 \%$ relative (Linde Gas Benelux B.V., Dieren, The Netherlands). Average values for oxygen uptake $\left(\mathrm{VO}_{2}\right)$ and carbon dioxide production $\left(\mathrm{VCO}_{2}\right)$ were calculated over the last 2 minutes of each 3 minutes stage, during which the RER was $<1 . V_{2}$ max was calculated as the average oxygen uptake of the 3 highest sequent oxygen uptakes during the last $60 \mathrm{~s}$ of the cycle test. Stages of 3 min can be used to accurately determine $\mathrm{VO}_{2}$ max [15]. Fat and carbohydrate oxidation and energy expenditure were calculated using stoichiometric equations and appropriate energy equivalents, with the assumption that the urinary nitrogen excretion rate was negligible during the cycle test.

Heart rate was recorded continuously during the test by using a radio telemetry heart rate monitor (Polar S610, Polar Electro Ltd., Oy, Finland).

\subsection{Physical activity}

To determine physical activity the Baecke questionnaire was used. This validated questionnaire explained $48 \%$ of the variation in Physical
Activity Level (PAL) as measured with doubly labeled water [16]. The Baecke questionnaire consists of three components: work activity, sports activity and leisure activity.

\subsection{Blood samples}

Fasting venous blood samples were taken to determine concentrations of plasma FFA, TAG. The blood samples were collected in tubes containing EDTA to prevent clotting. Plasma was obtained by centrifugation $\left(1500 \times \mathrm{g}\right.$ for $10 \mathrm{~min}$ at $4{ }^{\circ} \mathrm{C}$ ), frozen in liquid nitrogen and stored at $-80^{\circ} \mathrm{C}$ until analysis. FFA concentrations were measured using the Wako NEFA C-kit (Wako Chemicals, Neuss, Germany).

\section{Statistical analysis}

Groups were compared by ANOVA. Changes over time within groups were compared by 2 -tailed paired Student $t$-tests. Regression analyses were used to analyze the relation between fat oxidation and body composition or protein intake. All analyses were performed with the Statistical Package for the Social Sciences (SPSS) version 16.0.2 for Macintosh OS X. Differences were regarded as significant if $P<0.05$.

\section{Results}

Body weight and BMI did not change significantly over the intervention period (Table 1). Protein intake determined according to 24-h urinary nitrogen was significantly different between the protein and control group during the 3-months of intervention ( $80 \pm 21$ vs. $59 \pm 11 \mathrm{~g}, P<0.05$; or $1.2 \pm 0.2$ vs. $0.9 \pm 0.1 \mathrm{~g} / \mathrm{kg}$ body weight, $P<0.05)$. The protein group significantly increased in protein intake $(11 \pm 14 \mathrm{~g}$, $P<0.05$; and $0.1 \pm 0.2 \mathrm{~g} / \mathrm{kg}$ body weight, $P<0.05$ ). Baseline protein intake did not differ between groups.

Fat $_{\text {max }}$ significantly increased in the protein group $(0.08 \pm 0.08 \mathrm{~g} / \mathrm{min}$, $P<0.01$ ). Taking covariate change in body weight or change in $\mathrm{VO}_{2} \mathrm{max}$ into account Fat ${ }_{\max }$ still significantly increased in the protein group $(P<0.05)$. Taking change in FFM into account, Fat $_{\max }$ changed as a trend $(P=0.060)$. Fat-free mass increased, and FM and fat percentage decreased over time in the protein group $(P<0.01, P<0.05, P<0.05)$, which resulted in a significant change in fat percentage over time between the protein and control group $(P<0.05)$. Total activity index of the Baecke questionnaire and its subscores sport, leisure time and work, $\mathrm{VO}_{2} \mathrm{max}$ and $\mathrm{VO}_{2} \mathrm{max} / \mathrm{FFM}$ did not change.

The increase in $\mathrm{Fat}_{\max }$ in the protein group was a function of the increase in protein intake $(r=0.623, P<0.05)$. So, increased protein intake explained $39 \%$ of the variation in increased Fat ${ }_{\text {max }}$. At baseline, Fat $_{\max }$ was a function of body weight $(r=0.621, P<0.05)$, FFM $(r=0.604, P<0.05)$, and $\mathrm{VO}_{2} \max (r=0.621, P<0.05)$. Change in $\mathrm{Fat}_{\max }$ was not a function of change in body weight, change in FFM, or change in $\mathrm{VO}_{2}$ max.

At baseline, all subjects cycled on average $25 \mathrm{~min} 52 \mathrm{~s} \pm 3$ min $37 \mathrm{~s}$ and reached a maximal power output of $226 \pm 67 \mathrm{~W}$ and maximal heart rate of $187 \pm 7$ beats per minute during the graded bicycle test to exhaustion. Fig. 1 illustrates subjects' fat oxidation in function of their $\mathrm{VO}_{2} \max$ and power output during the bicycle test at baseline. Fat $_{\max }$ was $0.43 \pm 0.10 \mathrm{~g} / \mathrm{min}$ at $51 \pm 10 \% \mathrm{VO}_{2} \mathrm{max}$, and at a power output of $97 \pm 35 \mathrm{~W}$ and a heart rate of $130 \pm 16$ beats per minute. Fat $_{\text {max }}$ resulted in $63 \pm 17 \%$ of energy expenditure with a carbohydrate oxidation of $0.65 \pm 0.46 \mathrm{~g} / \mathrm{min}$.

\section{Discussion}

Increase in protein intake, without an increase in physical activity or fitness, increased stimulated fat oxidation and FFM independently of body weight over a 3-month intervention period. The change in protein intake explained $39 \%$ of the variation in change in stimulated fat 


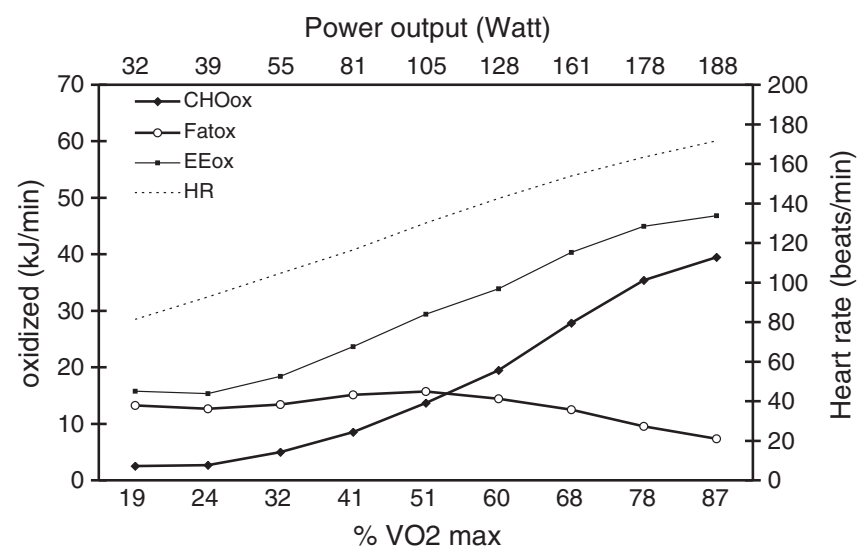

Fig. 1. Fat oxidation in function of $\mathrm{VO}_{2}$ max and power output during a graded bicycle test to exhaustion. CHOox is the amount of carbohydrate oxidized in $\mathrm{kJ} / \mathrm{min}$. Fatox is the amount of fat oxidized in $\mathrm{kJ} / \mathrm{min}$. EEox is the amount of total energy expenditure in $\mathrm{kJ} / \mathrm{min}$. HR is heart rate in beats/min.

oxidation during the incremental bicycle test. The variation in this Fat $_{\max }$ was mainly determined by protein intake and FFM.

An increase in protein content of the diet results into a shift in 24h substrate balances [17]. Protein balance shifts toward a positive balance and fat balance shifts toward a negative balance. In our subjects these shifts in macronutrient balances resulted in an increase in FFM and a decrease in FM and fat percentage without a change in body weight over a period of 3 months. The negative fat balance and subsequent decrease in FM imply that overall more fatty acids were transported out of the FM into the circulation instead of being transported into the FM as a fat-deposit. In line with this perspective, the dietary fat oxidation was previously inversely related to fat percentage and BMI, with lean subjects having the highest and obese subjects the lowest values of dietary fat oxidation [18]. Therefore, lean subjects could take up less dietary fat in their FM as a fat-deposit. Moreover, a lower ratio of FM to FFM results in a higher daily energy expenditure within a subject, as FFM is determining the resting metabolic rate [19] as well as 24-h energy expenditure [20]. The relationship between a positive protein balance, muscle protein synthesis, and change in FFM has only been suggested but has not been determined quantitatively. Part of this relationship has been revealed; protein rich diets result into net muscle-protein synthesis $[10,21,22]$, and increase energy expenditure due to the high ATP cost of protein synthesis $[23,24]$. This elevated energy expenditure is mainly derived from fat oxidation, as it is the preferred substrate of muscle during resting conditions $[25,26]$. Synthesis and breakdown of muscle protein contribute to the energy expenditure of resting muscle [9]. Thus, increase in total FFM leads to an increase in total energy expenditure. So, a shift in body composition into a more favorable one, i.e. increased FFM at the cost of FM, could have an impact on energy expenditure prior to exercise. So, the increased FFM coinciding with the increased protein intake could have influenced the stimulated fat oxidation during exercise of the bicycle test.

Body composition, stimulated fat oxidation and protein intake have been determined with high accuracy. Combination of densitometry with measurements of total body water and bone mineral content determined the 4-compartment model of subjects' body composition. Furthermore, we used 24-h urine nitrogen concentrations, which are more applicable to quantify protein intakes because dietary record methods are prone to misreporting [27]. The graded bicycle test with continuous indirect calorimetric measurements allowed precise determination of maximal fat oxidation.

The relative exercise intensity that elicited maximal fat oxidation of $51 \% \mathrm{VO}_{2}$ max after an overnight fast in our subjects is comparable with $43-64 \% \mathrm{VO}_{2}$ max observed in previous studies after an overnight fast in trained and untrained men $[28,29]$ and with $48-56 \% \mathrm{VO}_{2}$ max in a post-absorptive state $3-4 \mathrm{~h}$ after a meal in men and women $[30,31]$.

The 4-compartment method to determine the body composition used, the biomarker nitrogen used to determine the amount of daily protein intake, and the graded exercise test to exhaustion with simultaneous indirect calorimetric breath-by-breath measurements used to determine the maximum fat oxidation are the strengths of this study. Regardless of the significant findings presented, the limited amount of subjects is a limitation of the study, which limits the possibility to examine whether the association between change in Fat $_{\text {max }}$ and change in protein intake is mediated and modified by change in body composition and change in physical activity, respectively.

In conclusion, in subjects with increased protein intake stimulated fat oxidation was increased. Stimulated fat oxidation was a function of protein intake, body composition and $\mathrm{VO}_{2}$ max. Yet, change in stimulated fat oxidation was mainly a function of change in protein intake.

\section{Acknowledgments}

We gratefully acknowledge Loek Wouters and Paul Schoffelen for their assistance. The study was supported by Top Institute Food and Nutrition (TIFN, Wageningen, The Netherlands). SS designed the experiment, collected the data, analyzed the data, and wrote the manuscript. MSW-P designed the experiment, helped analyze the data and wrote the manuscript, and supervised the project. GP and AS helped collecting the data, reviewed the manuscript and provided critical comment. None of the authors had any financial or personal interest in any company or organization sponsoring the research.

\section{References}

[1] Mittendorfer B, Fields DA, Klein S. Excess body fat in men decreases plasma fatty acid availability and oxidation during endurance exercise. Am J Physiol Endocrinol Metab 2004;286:E354-62.

[2] Kelley DE, Goodpaster B, Wing RR, Simoneau JA. Skeletal muscle fatty acid metabolism in association with insulin resistance, obesity, and weight loss. Am J Physiol 1999;277:E1130-41.

[3] Romijn JA, Coyle EF, Sidossis LS, et al. Regulation of endogenous fat and carbohydrate metabolism in relation to exercise intensity and duration. Am J Physiol 1993;265:E380-91.

[4] Hickner RC, Privette J, Mclver K, Barakat H. Fatty acid oxidation in AfricanAmerican and Caucasian women during physical activity. J Appl Physiol 2001;90: 2319-24.

[5] Lejeune MP, Kovacs EM, Westerterp-Plantenga MS. Additional protein intake limits weight regain after weight loss in humans. Br J Nutr 2005;93:281-9.

[6] Westerterp-Plantenga MS, Lejeune MP, Nijs I, van Ooijen M, Kovacs EM. High protein intake sustains weight maintenance after body weight loss in humans. Int J Obes Relat Metab Disord 2004;28:57-64.

[7] Skov AR, Toubro S, Ronn B, Holm L, Astrup A. Randomized trial on protein vs carbohydrate in ad libitum fat reduced diet for the treatment of obesity. Int J Obes Relat Metab Disord 1999;23:528-36.

[8] Baba NH, Sawaya S, Torbay N, Habbal Z, Azar S, Hashim SA. High protein vs high carbohydrate hypoenergetic diet for the treatment of obese hyperinsulinemic subjects. Int J Obes Relat Metab Disord 1999;23:1202-6.

[9] Wolfe RR. The underappreciated role of muscle in health and disease. Am J Clin Nutr 2006;84:475-82.

[10] Harber MP, Schenk S, Barkan AL, Horowitz JF. Effects of dietary carbohydrate restriction with high protein intake on protein metabolism and the somatotropic axis. J Clin Endocrinol Metab 2005;90:5175-81.

[11] Lohman TG. Advances in Body Composition Assessment. 1st ed. IL: Champaign; 1992.

[12] Westerterp KR, Wouters L, van Marken Lichtenbelt WD. The Maastricht protocol for the measurement of body composition and energy expenditure with labeled water. Obes Res 1995;3(Suppl 1):49-57.

[13] Schoeller DA, van Santen E, Peterson DW, Dietz W, Jaspan J, Klein PD. Total body water measurement in humans with 180 and $2 \mathrm{H}$ labeled water. Am J Clin Nutr 1980;33:2686-93.

[14] Achten J, Gleeson M, Jeukendrup AE. Determination of the exercise intensity that elicits maximal fat oxidation. Med Sci Sports Exerc 2002;34:92-7.

[15] Bishop D, Jenkins DG, Mackinnon LT. The effect of stage duration on the calculation of peak VO2 during cycle ergometry. J Sci Med Sport 1998;1:171-8.

[16] Philippaerts RM, Westerterp KR, Lefevre J. Doubly labelled water validation of three physical activity questionnaires. Int J Sports Med 1999;20:284-9.

[17] Lejeune MP, Westerterp KR, Adam TC, Luscombe-Marsh ND, WesterterpPlantenga MS. Ghrelin and glucagon-like peptide 1 concentrations, 24-h satiety, and energy and substrate metabolism during a high-protein diet and measured in a respiration chamber. Am J Clin Nutr 2006;83:89-94. 
[18] Westerterp KR, Smeets A, Lejeune MP, Wouters-Adriaens MP, WesterterpPlantenga MS. Dietary fat oxidation as a function of body fat. Am J Clin Nutr 2008;87:132-5.

[19] Halliday D, Hesp R, Stalley SF, Warwick P, Altman DG, Garrow JS. Resting metabolic rate, weight, surface area and body composition in obese women. Int J Obes 1979;3:1-6.

[20] Ravussin E, Lillioja S, Anderson TE, Christin L, Bogardus C. Determinants of 24-hour energy expenditure in man. Methods and results using a respiratory chamber. J Clin Invest 1986;78:1568-78.

[21] Phillips SM. Physiologic and molecular bases of muscle hypertrophy and atrophy: impact of resistance exercise on human skeletal muscle (protein and exercise dose effects). Appl Physiol Nutr Metab 2009;34:403-10.

[22] Paddon-Jones D, Sheffield-Moore M, Zhang XJ, et al. Amino acid ingestion improves muscle protein synthesis in the young and elderly. Am J Physiol Endocrinol Metab 2004;286:E321-8.

[23] Tessari P, Kiwanuka E, Zanetti M, Barazzoni R. Postprandial body protein synthesis and amino acid catabolism measured with leucine and phenylalanine-tyrosine tracers. Am J Physiol Endocrinol Metab 2003;284:E1037-42.
[24] van Milgen J. Modeling biochemical aspects of energy metabolism in mammals. J Nutr 2002;132:3195-202.

[25] Halton TL, Hu FB. The effects of high protein diets on thermogenesis, satiety and weight loss: a critical review. J Am Coll Nutr 2004;23:373-85.

[26] Rasmussen BB, Wolfe RR. Regulation of fatty acid oxidation in skeletal muscle. Annu Rev Nutr 1999;19:463-84.

[27] Westerterp KR, Goris AH. Validity of the assessment of dietary intake: problems of misreporting. Curr Opin Clin Nutr Metab Care 2002;5:489-93.

[28] Nordby P, Saltin B, Helge JW. Whole-body fat oxidation determined by graded exercise and indirect calorimetry: a role for muscle oxidative capacity? Scand J Med Sci Sports 2006;16:209-14.

[29] Achten J, Jeukendrup AE. Maximal fat oxidation during exercise in trained men. Int J Sports Med 2003;24:603-8.

[30] Stisen AB, Stougaard O, Langfort J, Helge JW, Sahlin K, Madsen K. Maximal fat oxidation rates in endurance trained and untrained women. Eur J Appl Physiol 2006;98:497-506.

[31] Venables MC, Achten J, Jeukendrup AE. Determinants of fat oxidation during exercise in healthy men and women: a cross-sectional study. J Appl Physiol 2005;98:160-7. 